\title{
Suicide as an Inflammatory Process: A CRP-based Case-control Study
}

Özkıyım Enflamatuvar Bir Süreç mi? CRP Temelli Bir Olgu-kontrol Çalışması

\author{
(D) Gamze Gökalp1, (D) Emel Berksoy2, (D) Şefika Bardak2, (1) Şule Demir2, (D) Gülşah Demir2, (D) Murat Anıl3 \\ 1 Izmir Katip Çelebi University Faculty of Medicine, Department of Child Health and Diseases, Clinic of Pediatric Emergency, Izmir, Turkey \\ 2 Izmir Tepecik Training and Research Hospital, Clinic of Child Health and Diseases, Division of Child Emergency, Izmir, Turkey \\ 3izmir Democracy University Faculty of Medicine, Department of Child Health and Diseases, Izmir, Turkey
}

\section{Abstract}

Introduction: The number of suicide attempts and related deaths among adolescents is increasing every day. Although suicide presents a problem for the general population, it is a more serious problem for those with psychiatric diseases. Previous studies demonstrated the association between inflammation and psychiatric disease. Thus, we aim to investigate the relationship between adolescent suicide attempts and the inflammatory biomarker C-reactive protein (CRP).

Methods: This research was designed as a case-control study. The study population consisted of patients who been admitted to the pediatric emergency department between 01.03.2016 and 01.03.2019 following a suicide attempt. Healthy volunteers of similar age and gender characteristics who had been admitted to the pediatric clinic for routine examination were also recruited. The groups were compared in terms of demographic and clinical features and serum CRP levels.

Results: A total of 239 patients (108 patients and 131 controls) were included in the study. No difference in terms of demographic data was noted between the groups. The serum CRP levels of the control and suicide groups were $1.5 \pm 1.5$ and $12.7 \pm 6.4 \mathrm{mg} / \mathrm{L}$, respectively $(p<0.01)$. The mean serum CRP levels of cases with and without psychiatric disorders were $14.3 \pm 4.2$ and $9.7 \pm 2.7 \mathrm{mg} / \mathrm{L}$, respectively $(p=0.03)$.

Conclusion: Levels of CRP, a strong inflammatory marker, were higher in patients who had attempted suicide than in those who had not. CRP levels were also higher in patients with a psychiatric disease than in those without.

Keywords: Suicide, inflammation, CRP

\section{Öz}

Giriş: Çocukluk çağı özkıyım girişimi sayısı ve buna bağlı ölümler gün geçtikçe artmaktadır. Bu durum tüm popülasyon için bir sorun teşkil etse de psikiyatrik hastalığa sahip olanlar için daha ciddi bir sorundur. Önceki çalışmalar enflamasyon ile psikiyatrik hastalık birlikteliğini göstermiştir. Biz de buradan yola çıkarak çocukluk çağı özkıyım girişimleri ile enflamatuvar bir biyomarker olan C-reaktif protein (CRP) ilişkisini araştırmayı planladık.

Yöntemler: Çocuk acil servisine 01.03.2016-01.03.2019 tarihleri arasında özkıyım girişimi nedeniyle başvuran ve çalışmaya katılmayı kabul eden çalışma grubu ve sağlıklı gönüllü bireylerden oluşmuş kontrol grubu ile yapılan bu araştırma ileriye yönelik karakterde bir olgu-kontrol çalışması olarak dizayn edilmiştir. Her iki grubun demografik ve klinik verilerine ilaveten CRP düzeyleri incelenmiştir. Tüm bu parametreler açısından gruplar karşılaştırılmıştır.

Bulgular: Çalışmaya 108 olgu, 131 kontrol olmak üzere toplam 239 olgu dahil edilmiştir. Gruplar arasında demografik veriler açısından fark tespit edilmemiştir. Serum CRP düzeyleri açısından gruplar değerlendirildiğinde kontrol grubunun ortalaması 1,5 $\pm 1,5 \mathrm{mg} / \mathrm{L}$

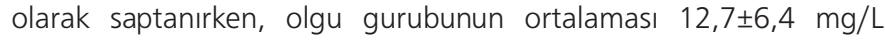
olarak bulunmuştur. $(p<0,01)$ Psikiyatrik hastalık varlığı açısından değerlendirildiğinde, CRP düzeyi, psikiyatrik hastalık tanısı almış grupta ortalama $14,3 \pm 4,2 \mathrm{mg} / \mathrm{L}$ olarak saptanırken, psikiyatrik

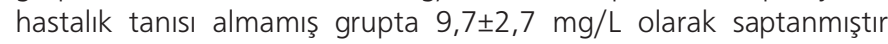
$(p=0,03)$.

Sonuç: Özkıyım girişiminde bulunan bireylerde kuvvetli bir enflamatuvar belirteç olan CRP normal popülasyona göre yüksek saptanmıştır. Bu klinik süreç ile ilgili enflamasyonun rolünün daha ayrıntılı bir şekilde incelenmesi gerekmektedir.

Anahtar Kelimeler: Özkıyım, enflamasyon, CRP

Address for Correspondence/Yazışma Adresi: Gamze Gökalp, İzmir Katip Çelebi University Faculty of Medicine, Department of Child Health and Diseases, Clinic of Pediatric Emergency, İzmir, Turkey

E-mail: drgamzegokalp@gmail.com ORCID ID: orcid.org/0000-0001-9467-3617 Received/Geliş Tarihi: 04.06.2020 Accepted/Kabul Tarihi: 05.02.2021 


\section{Introduction}

The numbers of adolescent suicide attempts and deaths due to suicide have increased over time. According to a World Health Organization report, suicide accounted for 1.4\% of all deaths worldwide in 2004. ${ }^{1}$ Suicidal thoughts occur much more frequently than suicidal attempts. Approximately $13 \%$ of the population report having had these thoughts during their lives. ${ }^{2}$ This rate is even higher among those with psychiatric diseases, with some studies revealing $40 \%$ of patients experiencing suicidal ideation within the first 5 years after diagnosis. ${ }^{3.5}$

Inflammation and tissue damage may cause some protein levels in the blood to increase. These increased proteins, including C-reactive protein (CRP), serum amyloid $A$, procalcitonin, and interleukin (IL)-6, are generally called acute-phase reactants. ${ }^{6,7}$ CRP is the most commonly used molecule in emergency departments because it is the least expensive one. ${ }^{8}$ CRP is mainly synthesized in hepatocytes. Trauma, infectious diseases, autoimmune diseases, infarcts, and neoplasms can increase the serum level of CRP. Serum levels of this molecule are known to increase because of inflammation. Psychological stress, behavioral changes, nutritional imbalances, and biochemical changes may affect the production of acute-phase reactants.., 10 Prolonged starvation, fatigue, insomnia, exercise, iron deficiency, and zinc deficiency may also elevate levels of acute-phase reactants in the presence of inflammatory disease. ${ }^{11-13}$

When the pathophysiology that causes suicide is investigated, inflammation is one of the mechanisms identified. ${ }^{14}$ Previous studies found high levels of IL-2 and IL- 6 in the cerebrospinal fluid and peripheral blood samples of patients who had attempted suicide. ${ }^{14,15}$ Postmortem examination of brain tissue samples from individuals who had died by suicide show increased inflammation. ${ }^{16}$ The immunohistochemical staining of CRP in the hippocampal region is noteworthy. ${ }^{17}$ Although some studies noted increased cytokine levels in patients with depression, different cytokine profiles have been observed in persons who have attempted suicide. ${ }^{18}$ In addition, although several biomarkers show higher expression during inflammation, the relationship between CRP and mental function is especially remarkable.

Our first aim is to investigate whether serum CRP levels differ between the healthy population and patients who had attempted suicide. Our second aim is to compare the serum CRP levels of patients with and without psychiatric disorders among suicidal individuals.

\section{Materials and Methods}

This study was conducted in the pediatric emergency department of the university hospital located in the city center between 01.03.2016 and 01.03.2019. This research was designed as a case-control study and given approval by the Local Ethics Committee, İzmir Katip Çelebi University (date: 08.08.2019, no: 340). Consent forms were obtained from the legal guardian of the participants because of the age of our patients $(<18$ years $)$.

\section{Cases}

The study group consisted of cases who were admitted to the pediatric emergency department because of a suicide attempt. We included only patients with drug intoxication as a suicidal intervention method. We did not include cases who attempted suicide with other methods (e.g., hanging, falling from a certain height). The control group included volunteer children and adolescents of similar age, gender, and ethnic characteristics who were admitted to the pediatric clinic for routine examination. Patients whose white blood cell counts were high than normal values for their age were excluded from the control group (to eliminate possible infectious disease). The demographic and clinical data of both groups were recorded. Serum CRP levels were also examined for both groups. In the suicide group, the CRP value was obtained at the first admission to the emergency room. In the control group, serum samples were taken at the time of application to the clinic. The groups were compared in terms these parameters. Subjects in the suicide group were further categorized as those who had a psychiatric diagnosis and those who did not. The inclusion criteria for the case group were as follows: (1) came to the pediatric emergency department because of a suicide attempt and (2) agreed to participate in the study. The exclusion criteria were as follows: (1) taking any medication that changes blood biochemical values, (2) previous infectious or inflammatory disease, (3) pregnancy confirmed by elevated serum B-human chorionic hormone levels, (3) abnormal values in complete blood count (to eliminate possible infectious disease), (4) diagnosed with any chronic disease, (5) chronic use of drugs or other substances, (6) exposure to an antibiotic or anti-inflammatory agent during the week, (7) body mass index higher than +2 standard deviations, and (8) did not agree to participate in the study. Psychiatric evaluation for cases who attempted suicide was performed by a child and adolescent psychiatric specialist.

\section{Laboratory Analysis}

Serum CRP levels were measured via the particle-enhanced immunoturbimetric method using the Diamention RCRP system (Siemens Medical Solutions, USA) in the biochemistry laboratory of the hospital. Normal CRP values vary by age and ethnicity. According to a report published by the National Health and Nutrition Evaluation Survey in 2005, 48\% of 
21,000 healthy subjects had a CRP level of $<2 \mathrm{mg} / \mathrm{L}, 43 \%$ had a CRP level of 2-10 mg/L, and of $8 \%$ had a CRP level of $>10 \mathrm{mg} / \mathrm{L} .{ }^{19}$ Because each laboratory has a unique cut-off value, we used " $5 \mathrm{mg} / \mathrm{L}$," which is the cut-off value of our laboratory.

\section{Statistical Analysis}

The data were analyzed using SPSS 20.0 (SPSS Inc., IL, US), and the results were presented as mean (standard deviation) or number (\%) where applicable. An independent t-test was used when only two groups were compared. Chi-squared analysis was performed to compare categorical data; when the chi-squared assumption did not meet the criteria, Fisher's Exact test was performed. The alpha-level of significance was set at $p<0.05$.

\section{Results}

A total of 239 patients (108 cases and 131 controls) were included in the study. The control group consisted of 121 (92.4\%) females and 10 (7.9\%) males, while the case group consisted of 102 (94.4\%) females and $6(5.6 \%)$ males ( $p=0.5)$. The mean ages of the patient and control groups were $15.1 \pm 2$ and $15.7 \pm 1.3$ years, respectively $(p=0.1)$. In the case group, 103 cases $(95.4 \%)$ were found to be residents and $5(4.6 \%)$ were immigrants. In the control group, 126 cases (96.1\%) were residents and 5 (3.9\%) were immigrants. The case and control groups were similar in terms of demographic data (Table 1).

In the case group, 74 children (68.5\%) were diagnosed with psychiatric disorders by a child and adolescent psychiatric specialist. Of these, 35 (32.5\%) were diagnosed with major depressive disorder, $30(27.7 \%)$ were diagnosed with impulse control disorder, 6 (5.5\%) were diagnosed with generalized anxiety disorder, and 3 cases (2.8\%) were diagnosed with other disorders (Table 2).
When the groups were evaluated in terms of serum CRP level, which constitutes the main construct of the study, the mean serum CRP levels of the control and case groups were 1.5 \pm 1.5 and $12.7 \pm 6.4 \mathrm{mg} / \mathrm{L}$, respectively [ $\mathrm{t}=3.7, \mathrm{p}<0.01$ (t-test); Table 3].

According to the reference values reported by the National Health and Nutrition Evaluation Survey in 2005, serum CRP levels were found to be normal in $119(90.8 \%)$ cases in the control group and high in $12(9.2 \%)$ patients in the control group. In the suicide group, 28 (25.9\%) cases showed normal whereas $80(74.1 \%)$ cases showed high serum CRP levels. Thus, the level of CRP in the suicide group was significantly higher than that in the control group $(p<0.01$, Table 4$)$.

When the groups were evaluated in terms of the presence of psychiatric disorders, the mean serum CRP level was 14.3 \pm 4.2 $\mathrm{mg} / \mathrm{L}$ in cases with a psychiatric disorder and $9.7 \pm 2.7 \mathrm{mg} / \mathrm{L}$ in cases without a psychiatric disorder [ $\mathrm{t}=1.4, \mathrm{p}=0.03$ (t-test); Table 5].

\section{Discussion}

The primary aim of this study is to investigate whether serum CRP levels differ between the healthy population and those who had attempted suicide. We found that serum CRP levels are significantly higher in cases who had attempted suicide than in those who had not. The secondary aim of this study is to investigate whether serum CRP levels differ between cases who have psychiatric disorders and those who do not in the suicide group. We found that serum CRP levels are significantly higher in the former than in the latter.

When studying the association between serum CRP level and suicide attempt, two important questions arise. First, could a suicide event be triggered by a pre-existing inflammation? Second, is inflammation triggered after a suicide attempt?

Table 1. Gender, ethnicity, and age characteristics of the study groups

\begin{tabular}{|c|c|c|c|c|c|c|c|}
\hline & \multicolumn{2}{|l|}{$\begin{array}{l}\text { All cases } \\
n=239, \%\end{array}$} & \multicolumn{2}{|c|}{$\begin{array}{l}\text { Control group } \\
n=131, \%\end{array}$} & \multicolumn{2}{|c|}{$\begin{array}{l}\text { Suicide group } \\
\mathrm{n}=108, \%\end{array}$} & $p$ \\
\hline \multicolumn{8}{|l|}{ Gender } \\
\hline Female & 223 & 93.3 & 121 & 92.4 & 102 & 94.4 & 0.5 \\
\hline Male & 16 & 6.7 & 10 & 7.9 & 6 & 5.6 & - \\
\hline Total & 239 & 100 & 131 & 100 & 108 & 100 & - \\
\hline \multicolumn{8}{|l|}{ Ethnicity } \\
\hline Immigrant & 10 & 4.2 & 5 & 3.9 & 5 & 4.6 & - \\
\hline Total & 239 & 100 & 131 & 100 & 108 & 100 & - \\
\hline \multicolumn{8}{|l|}{ Age (years) } \\
\hline Mean $\pm S D(\min / \max )$ & $15.5 \pm 1.7(7 / 18)$ & & $15.7 \pm$ & & 15.1 & & 0.1 \\
\hline
\end{tabular}


The available studies support both opinions. For example, some studies have found that previous inflammation triggers suicidal ideation. Patients taking interferon- $\alpha 2 b$, which has anti-inflammatory effects on chronic hepatitis $C$, were found to have a lower rate of suicidal ideation compared with the group who had not taken the drug. In other words, reducing inflammation could reduce suicidal ideation. ${ }^{20}$

Other studies supporting the belief that suicide triggers inflammation hold that negative thoughts and a lack of plans for the future are related to depression, which itself is a cause of inflammation. These thoughts are stressors for patients. ${ }^{21,22}$ Depression increases the level of cytokines, such as IL-2 and IL-6, and these cytokines stimulate the production of CRP in hepotocytes. ${ }^{14,16}$

Some researchers, however, emphasize that the issue of which triggers the other is not important but the close relationship between these factors is undeniable as the results of many studies could be interpreted as "the serum

Table 2. Psychiatric diseases in the suicide group

\begin{tabular}{|lll|}
\hline & $\mathbf{n = 1 0 8}$ & $\%$ \\
\hline Psychiatric disorders & $\mathbf{7 4}$ & $\mathbf{6 8 . 5}$ \\
\hline Impujor depressive disorder & $35^{*}$ & $32.5^{*}$ \\
\hline Generalized anxiety disorder & $30^{*}$ & $27.7^{*}$ \\
Other diseases & $6^{*}$ & $5.5^{*}$ \\
No psychiatric disorder & $3^{*}$ & $2.8^{*}$ \\
Total & $\mathbf{3 4}$ & $\mathbf{3 1 . 5}$ \\
\hline${ }^{*}$ Data show the distribution of the total number of psychiatric disorders diagnosed
\end{tabular}

inflammatory cytokine levels of patients with depression and attempted suicide are higher than those with depression but did not attempt suicide". ${ }^{23-25}$ One of these studies is a cohort study that included 517 cases. Suchankova et al. ${ }^{26}$ studied the $+1444 \mathrm{~T}$ allele of the gene responsible for the production of CRP in patients who had and had not attempted suicide. The researchers concluded that the allele of the gene is more highly expressed in patients who had attempted suicide than in those who had not. ${ }^{26}$ In another study, Tonelli et al..$^{27}$ found that the mRNA levels of IL-4 and IL-13, which are inflammatory mediators found in the orbitofrontal cortex of patients who had died due to suicide, were expressed at very high levels compared with those found in patients who had died of other causes. Lindqvist et al. ${ }^{15}$ found that IL-6 levels were very high in individuals who had attempted suicide. O'Donavan et al. ${ }^{28}$ also demonstrated that IL-6, IL-10, and CRP levels are significantly higher in cases with a high degree of suicidal ideation than in those individuals without suicidal ideation.

However, some reports in the literature indicate that the etiology of depression is not associated with inflammation. ${ }^{29-31}$ For example, Whooley et al. ${ }^{32}$ and Glassman and Miller ${ }^{33}$ found no association between these factors. These studies indicated the presence of inflammation in patients with suicide ideation, but some other underlying mechanisms may have been present as confounding factors. Therefore, we excluded individuals with acute/chronic diseases or drug use from our study.

CRP was used as an inflammatory biomarker in our study because of its easy accessibility. However, CRP is also non-

Table 3. Serum CRP levels among the case and control groups (Student's t-test)

\begin{tabular}{|c|c|c|c|c|}
\hline & $\begin{array}{l}\text { All cases } \\
n=239 \\
(\text { Mean } \pm \text { SD })\end{array}$ & $\begin{array}{l}\text { Control group } \\
n=131 \\
(\text { Mean } \pm \text { SD) }\end{array}$ & $\begin{array}{l}\text { Suicide group } \\
n=108 \\
(\text { Mean } \pm \text { SD) }\end{array}$ & $\mathbf{p}$ \\
\hline CRP (mg/L) & $6.6 \pm 3.8$ & $1.5 \pm 1.5$ & $12.7 \pm 6.4$ & $<0.01$ \\
\hline
\end{tabular}

Table 4. Normal serum CRP levels among the case and control groups (chi-squared test)

\begin{tabular}{lllll} 
& $\begin{array}{l}\text { All cases } \\
\mathbf{n = 2 3 9 ,} \%\end{array}$ & $\begin{array}{l}\text { Control group } \\
\mathbf{n = 1 3 1 , \%}\end{array}$ & $\begin{array}{l}\text { Suicide group } \\
\mathbf{n = 1 0 8 ,} \%\end{array}$ \\
CRP situation & & $119,90.8 \%$ & $28,25.9 \%$ & $\mathbf{p}$ \\
Normal & $147,61.5 \%$ & $12,9.2 \%$ & $80,74.1 \%$ & - \\
High & $92,38.5 \%$ & $131,100 \%$ & $108,100 \%$ \\
\hline Total & $239,100 \%$ & & & - \\
CRP: C-reactive protein & & & \\
\hline
\end{tabular}

Table 5. Mean CRP levels in the suicide group (Student's t-test)

Suicide group

CRP $(\mathrm{mg} / \mathrm{L})$

Cases with psychiatric diseases

$\mathrm{n}=\mathbf{7 1}$ (Mean \pm SD)

$14.3 \pm 4.2$

CRP: C-reactive protein, SD: Standard deviation

\section{Cases without psychiatric diseases n=37 (Mean \pm SD)}

$9.7 \pm 2.7$

0.03 
specific molecule that is affected by many conditions. Although we had attempted to rule out confounding factors that may affect the outcome of this work, we recommend further study using a molecule more specific to neuroinflammation to obtain more accurate results. Our findings lay the foundation for future research on suicide in the adolescent population.

\section{Conclusion}

A positive relationship appears to exist between adolescent suicide attempts, adolescent psychiatric disorders, and serum CRP levels as an inflammatory mediator. Considering these relationships, we believe that repressing CRP-induced inflammation may be beneficial in terms of minimizing psychiatric diseases or suicidal thoughts in adolescents exposed to chronic inflammation. Studies with larger series and using molecules more specific to neuroinflammation are necessary to confirm the relationships discovered in this work.

\section{Acknowledgments}

We would like to thank the pediatric psychiatrist for their contribution to this study.

\section{Ethics}

Ethics Committee Approval: This research was designed as a case-control study and given approval by the Local Ethics Committee, İzmir Katip Çelebi University (date: 08.08.2019, no: 340$)$.

Informed Consent: Consent forms were obtained from the legal guardian of the participants because of the age of our patients $(<18$ years).

Peer-review: Externally peer-reviewed.

\section{Authorship Contributions}

Design: G.G., Data Collection or Processing: G.G., E.B., S..B., Ş.D., G.D., Analysis or Interpretation: G.G., E.B., Ş.B., Ş.D., G.D., Critical Control: M.A., Writing: G.G., E.B.

Conflict of Interest: No conflict of interest was declared by the authors.

Financial Disclosure: The authors declared that this study received no financial support.

\section{References}

1. World Health Organization Revised Global Burden of Disease(GBD); 2004. Available at: http://www.who.int/health info/global burden disease /2004reportupdateenindex.html

2. Kessler RC, Borges G, Walters EE. Prevalence of and risk factorsfor lifetime suicide attempts in the National Comorbidity Survey.Arch Gen Psychiatry. 1999;56:617-26

3. Malone KM, Haas GL, Sweeney JA, Mann JJ. Major depression andthe risk of attempted suicide. J Affect Disord. 1995;34:173-85.
4. Kushner I. The phenomenon of the acute phase response. Ann N Y Acad Sci. 1982;389:39-48.

5. Gabay C, Kushner I. Acute-phase proteins and other systemic responses to inflammation. N Engl J Med. 1999;340:448-54.

6. Gabay C, Smith MF, Eidlen D, Arend WP. Interleukin 1 receptor antagonist (IL-1Ra) is an acute-phase protein. J Clin Invest. 1997;99:2930-40.

7. Nemeth E, Valore EV, Territo M, Schiller G, Lichtenstein A, et al. Hepcidin, a putative mediator of anemia of inflammation, is a type II acute-phase protein. Blood. 2003;101:2461-3.

8. Malle E, De Beer FC. Human serum amyloid A (SAA) protein: a prominent acute-phase reactant for clinical practice. Eur J Clin Invest. 1996:26:427-35.

9. Prajitha N, Athira SS, Mohanan PV. Comprehensive biology of antipyretic pathways. Cytokine. 2019;116:120-7.

10. Goldbach JM, Roth J, Zeisberger E. Fever suppression by subdiaphragmatic vagotomy in guinea pigs depends on the route of pyrogen administration. Am J Physiol. 1997;272:R675-81.

11. Sarraf $P$, Frederich RC, Turner EM, Ma G, Jaskowiak NT, et al. Multiple cytokines and acute inflammation raise mouse leptin levels: potential role in inflammatory anorexia. J Exp Med. 1997;185:171-6.

12. Limanaqi F, Biagioni F, Gaglione A, Busceti $C L$, Fornai F. A Sentinel in the Crosstalk Between the Nervous andlmmune System: The (Immuno)-Proteasome. Front. Immunol. 2019;10:628.

13. Bone RC. Toward a theory regarding the pathogenesis of the systemic inflammatory response syndrome: what we do and do not know about cytokine regulation. Crit Care Med. 1996;24:16372.

14. Nassberger L, Traskman-Bendz L. Increased soluble interleukin-2 receptor concentrations in suicide attempters. Acta Psychiatr Scand. 1993;88:48-52.

15. Lindqvist $D$, Janelidze $S$, Hagell $P$, Erhardt $S$, Samuelsson $M$, et al. Interleukin- 6 is elevated in the cerebrospinal fluid of suicideattempters and related to symptom severity. Biol Psychiatry. 2009;66:287-92

16. Tonelli LH, Stiller J, Rujescu D, Giegling I, Schneider B, et al. Elevated cytokine expression in the orbitofrontal cortex of victims of suicide. Acta Psychiatr Scand. 2008;117:198-206.

17. Kok EH, Alanne-Kinnunen M, Isotalo K, Luoto T, Haikonen S, et al. CRP gene variation affects early development of Alzheimer's diseaserelatedplaques. J Neuroinflammation. 2011;8:96.

18. Janelidze S, Mattei D,Westrin A, Traskman-Bendz L, Brundin L. Cytokine levels in the blood may distinguish suicide attempters from depressed patients. Brain Behav Immun. 2011;25:335-9.

19. Woloshin S, Schwartz LM. Distribution of C-reactive protein values in the United States. N Engl J Med. 2005;352:1611-3.

20. Dieperink E, Ho SB, Tetrick L, Thuras P,Dua K, et al. Suicidal ideation during interferon-_2b and ribavirin treatment ofpatients with chronic hepatitis C. General Hospital Psychiatry. 2004;26:237-40.

21. MacLeod AK, Tata P, Tyrer P. Schmidt U, Davidson K, et al. Hopelessness and positiveand negative future thinking in parasuicide. Br J Clin Psychol. 2005;44:495-504.

22. O'Donovan A, Lin J, Dhabhar FS, Wolkowitz OM, Tillie JB, et al. Pessimism correlates withleukocyte telomere shortness and elevated interleukin-6 in postmenopausalwomen. Brain Behav Immun. 2009;23:446-9. 
23. Dickerson SS, Gable SL, IrwinMR, Aziz N, Kemeny ME. Socialevaluative threatand proinflammatory cytokine regulation: an experimental laboratoryinvestigation. Psychol Sci. 2009;20:123744.

24. Dickerson SS, Kemeny ME. Acute stressors and cortisol responses:a theoretical integration and synthesis of laboratory research. Psych Bull. 2004;130:355-91.

25. Melamed S, Shirom A, Toker S, Berliner S, Shapira I. Association of fear of terrorwith low-grade inflammation among apparently healthy employedadults. Psychosom Med. 2004;66:484-91.

26. Suchankova P, Holm G, Traskman-Bendz L, Brundin L, Ekman A. The $+1444 C>T$ polymorphism in the CRP gene: a studyon personality traits and suicidal behaviour Psychiatric Genetics. 2013;23:70-6.

27. Tonelli LH, Stiller J, Rujescu D, Giegling I, Schneider B, et al. Elevated cytokine expression in the orbitofrontal cortex of victims of suicide. Acta Psychiatr Scand. 2008;117:198-206.

28. O'Donovan A, Rush G, Hoatam G, Hughes BM, McCrohan AM, et al. Suicidal ideation is associated with elevated inflammation in patients with major depressive disorder. Depression And Anxiety. 2013;30:307-14.
29. Maes M, Meltzer HY, Bosmans E, Bergmans R, Vandoolaeghe E, et al. Increased plasma concentrations of interleukin-6, soluble interleukin-6, soluble interleukin-2 and transferrin receptor in major depression. J Affect Disord. 1995;34:301-9.

30. Hestad KA, Tonseth S, Stoen CD, Ueland T, Aukrust P. Raised plasma levelsof tumor necrosis factor alpha in patients with depression:normalization during electroconvulsive therapy. J ECT. 2003;19:183-8.

31. O'Donovan A, Hughes BM, Slavich GM, Lynch L, Cronin MT, et al. Clinical anxiety, cortisol and interleukin-6: evidence for specificity in emotion biology relationships. Brain Behav Immun. 2010;24:10747.

32. Whooley MA, Caska CM, Hendrickson BE, Rourke MA, Ho J, et al. Depression and inflammation in patients with coronary heart disease: findings from the Heart and Soul Study. Biol Psychiatry. 2007;62:314-20.

33. Glassman AH, Miller GE. Where there is depression, there is inflammation ... sometimes! Biol Psychiatry. 2007;62:280-1. 